\title{
RETHINKING EUROSCEPTICISM IN TURKEY: GOVERNMENT, OPPOSITION AND PUBLIC OPINION
}

\section{Türkiye’deki Avrupa Şüpheciliğini Yeniden Düşünmek: Hükümet, Muhalefet ve Kamuoyu}

\section{Seçkin Barış GÜLMEZ*}

\author{
Keywords: \\ Euroscepticism, AKP, \\ CHP, MHP, Public \\ Opinion, Turkey
}

JEL Codes:

D72, D74, Z18

\section{Anahtar Kelimeler:}

Avrupa Şüpheciliği, AKP, CHP, MHP, Kamuoyu, Türkiye

JEL Kodları:

D72, D74, Z18

\begin{abstract}
This article aims to scrutinise the state of euroscepticism in Turkey with a particular focus on the shifting preferences of government, opposition and public opinion in the last decade. Building upon Y1lmaz's (2011) analysis, the article will try to make sense of the eurosceptic transformations in Turkish politics from 2008 onwards. Accordingly, first, shifting governmental discourses towards the EU will be discussed with a particular focus on how the AKP government adopted the 'Sévres Syndrome' as a key political tool to denigrate Europe. Second, euroscepticism in opposition parties will be scrutinised comparing the strategic eurosceptic rhetoric of the CHP with the ideologically-driven euroscepticism of the MHP. Final section will examine how Turkish public responds to the eurosceptic/pro-EU shifts in the discourses of major political parties. Overall, the article argues that euroscepticism in Turkish politics in the last decade often fluctuates between government and opposition in response to certain domestic political turning points appearing to be more strategic than ideologically-driven, more volatile than stable, and hence less and less credible.
\end{abstract}

\section{Özet}

$\mathrm{Bu}$ çalıșma, hükümet, muhalefet ve kamuoyunun değișen tercihlerine odaklanarak, son on yılda Türkiye'deki Avrupa şüpheciliğinin durumunu mercek altına almayı amaçlamaktadır. Çalışma, Yılmaz'ın (2011) analizinin üstüne koyarak, özellikle 2008 sonrası dönemde Türk siyasetindeki Avrupa şüpheci dönüşümü anlamlandırmaya çalışacaktır. Buna göre, öncelikle, hükümetin Avrupa'ya yönelik değişen söylemleri tartışılacak ve hükümetin Avrupayı kötüleme amacıyla "Sevr Sendromu"'nu nasıl önemli bir siyasi araç olarak kullandığı vurgulanacaktır. İkinci olarak, muhalefet partilerinde gözlenen Avrupa şüpheciliği ele alınacak ve CHP'nin stratejik şüpheci söylemiyle MHP'nin ideolojik şüpheci söylemi karşılaştırılacaktır. Son bölümde ana siyasi partilerin söylemlerindeki Avrupa şüpheci/Avrupa yanlısı değişime Türk kamuoyunun nasıl yanıt verdiği tartışılacaktır. Sonuç olarak, bu çalışma, Türk siyasetinin son on yılında gözlemlenen Avrupa şüphecisi tutumun önemli siyasi dönüm noktalarının etkisiyle kimi zaman hükümet, kimi zaman da muhalefet tarafından sahiplenildiğini vurgulamakta; bundan dolayı Türkiye'deki Avrupa şüpheciliğinin ideoloijk olmaktan ziyade stratejik, oldukça değişken ve bu yüzden de giderek daha az inandırıcı olduğunu savunmaktadır.

\footnotetext{
* Assist. Prof. Dr., Izmir Katip Çelebi University, Department of International Relations, Izmir, Turkey, seckinbaris.gulmez@ikcu.edu.tr, ORCID: 0000-0003-1690-1041
}

Makale Geliş Tarihi (Received Date): 04.02.2020 Makale Kabul Tarihi (Accepted Date): 18.03.2020 


\section{Introduction}

This article aims to tackle the overriding question of what determines the state of Euroscepticism in Turkey with a particular focus on the shifting preferences of government, opposition and public opinion in the last decade. Euroscepticism is defined in the scholarly literature as 'the idea of contingent or qualified opposition, as well as incorporating outright and unqualified opposition to the process of European integration' (Taggart, 1998, p. 366). Taggart and Szczerbiak (2004), in their seminal work, categorize Euroscepticism into Hard and Soft Euroscepticism. Accordingly, Hard Euroscepticism indicates an 'outright' and 'unqualified' opposition to European integration in which political actors firmly reject being a part of the European Union; while Soft Euroscepticism refers to a critical stance against certain EU policies such as single currency and single market, while being in favor of European integration in general (Taggart and Szczerbiak, 2004, pp. 4-5). Euroscepticism can be ideologically-driven. According to Marks, Hooghe, Nelson and Edwards (2006, p. 157), political actors with far Left or far Right ideological leanings or parties with a conservative political agenda might resort to Euroscepticism. Moreover, strategic calculations to weaken domestic opponents and increase popular support have been discussed in the literature as key determinants for eurosceptic policies (Hooghe and Marks, 2009, p. 19; Sitter, 2001, p. 25).

The scholarly literature is replete with analyses on eurosceptic politics in Turkey most of which either focus on one political party, compare two political actors or examine public opinion (Avc1, 2011; Başkan Canyaş and Gümrükçü, 2015; Baudner, 2012; Canefe and Bora, 2003; Celep, 2011; Dikici Bilgin, 2017; Gülmez, 2008, 2013a; 2013b; Güneş-Ayata, 2003; Öniş, 2007; Spiering, 2007; Tezcan and Aras, 2015). The seminal work by Y1lmaz (2011) offers the most comprehensive account on euroscepticism observed in major Turkish political parties as well as public opinion. His work is particularly instrumental to draw the boundaries of the eurosceptic status quo ante in Turkey since it successfully maps the state of euroscepticism in Turkey until 2008. Singling out the major opposition parties, namely, the Republican People's Party (CHP) and the Nationalist Action Party (MHP) as the key drivers of euroscepticism in Turkish politics with a particular reference to the 'Sévres Syndrome', Y1lmaz (2011) highlights the governing Justice and Development Party (AKP) as the key driver of europeanization in Turkey despite its pro-Islamic roots. Accordingly, as regards the 2007 elections, the popularity of eurosceptic political parties remained around 37\% (CHP 21\% and MHP 14\% and SP 2,3\%), while the AKP-led pro-EU parties became as popular as 57\% (AKP 47\%, Democrat Party [DP] 5\% and pro-Kurdish independent 5\%) (Habertürk 2007). Similarly, Yllmaz (2011, p. 187) traces a strong pro-EU stance within Turkish public at around 74\% at its highest in 2003 and 58\% at its lowest in 2007.

In the last ten years, however, a lot has changed both in the EU and Turkey almost resulting in the suspension of bilateral relations. The last decade could be considered as the decade of the EU's integration crisis, since the EU suffered major economic and political crises including the eurozone sovereign debt crisis, the Syrian refugee crisis and the Brexit. The first two crises had a particular impact on Turkey-EU relations contributing to the development of euroscepticism in Turkish politics. The eurozone crisis intensified the 'enlargement fatigue'

\footnotetext{
${ }^{1}$ The term refers to the infamous Treaty of Sévres in 1920, which foresaw the division of Turkey into several zones under foreign control. However, the Treaty was never realized as it was replaced with the Treaty of Lausanne in 1923.
} 
among EU member states constituting a structural hurdle to Turkey's EU accession (Vachudova, 2014, p. 125). Especially, the French decision to block several negotiating chapters followed by the statements of German and French leaders, Angela Merkel and Nicholas Sarkozy urging for a privileged partnership for Turkey inflamed eurosceptic discourses among Turkish political circles (Eylemer and Taş, 2007, p. 564). Moreover, the Syrian refugee crisis tested the resolve of Turkey-EU relations since the mass influx of refugees into Europe fleeing from the Syrian civil war forced an EU-Turkey refugee deal which also aimed to revitalize Turkey's EU bid (İçener, 2016). However, disagreements over the execution of the deal rather drew Turkey further away from the EU (Kaya, 2020). For its part, Turkey experienced critical junctures in its soil such as the Gezi protests in 2013 and the failed coup attempt in 2016 which further challenged Turkey's EU bid. These developments helped trigger a remarkable discursive as well as attitudinal shift in Turkish political circles towards the EU. Euroscepticism no longer remains an opposition phenomenon as the AKP government has turned out to be a strong critic of the $\mathrm{EU}$, while the CHP, the main opposition party, returned to pro-EU discourse over the last decade. As shown in table one, the popularity of eurosceptic parties in Turkey rose from $37 \%$ in 2007 to $65 \%$ in 2018, while that of pro-EU parties declined from 57\% in 2007 to $34 \%$ in 2018. Therefore, there is a need to reconsider the state of euroscepticism in Turkey in resonance with shifting political dynamics since 2008. This article offers two main contributions to the scholarly literature. Firstly, it picks up where Y1lmaz (2011) left off and furthers his research by focusing on the 2008-2018 period to provide a fresh and refined analysis on how euroscepticism in Turkey has been evolved in the last decade. In so doing, it, secondly, compares the shifting EU stances of mainstream Turkish political parties with those of the Turkish public opinion to better understand the dialectical relationship between political actors and public concerning the EU.

The article is organised into three parts. First, shifting governmental discourses towards the EU will be discussed with a particular focus on how the AKP government adopted the 'Sévres Syndrome' as a key political tool to denigrate Europe. Second, euroscepticism in opposition parties ${ }^{2}$ will be scrutinised comparing the strategic eurosceptic rhetoric of the CHP with the ideologically-driven euroscepticism of the MHP. Third and final section will examine how Turkish public responds to the eurosceptic/pro-EU shifts in the discourses of major political parties. Overall, the article argues that euroscepticism in Turkish politics tends to be more strategic than ideologically-driven, more volatile than stable, hence less credible. Public directly mirrors this trend which translates into an almost 50\% public support for the EU.

\footnotetext{
2 This article does not examine the Democratic Party of Nations (HDP) as it mostly refrains from euroscepticism in its discourses.
} 
Table 1: Comparison of Eurosceptic and Pro-EU Parties in 2007 and 2018 General Elections

\begin{tabular}{lll}
\hline & $\mathbf{2 0 0 7}$ & $\mathbf{2 0 1 8}$ \\
\hline AKP & $46,58 \%$ & $42,60 \%$ \\
CHP & $20,88 \%$ & $22,60 \%$ \\
MHP & $14,27 \%$ & $11,10 \%$ \\
DP & $5,42 \%$ & \\
Independent/HDP & $5,24 \%$ & $11,70 \%$ \\
IYİ PARTY & & $10 \%$ \\
SP & $2,34 \%$ & $1,30 \%$ \\
Other & $5,27 \%$ & $0,70 \%$ \\
Eurosceptic parties & $37,49 \%(\mathrm{CHP}+\mathrm{MHP}+\mathrm{SP})$ & $65 \%(\mathrm{AKP}+\mathrm{MHP}+\mathrm{I} Y \dot{I}+\mathrm{SP})$ \\
Pro-EU parties & $57,24 \%$ (AKP+DP+Indepedent) & $34,3 \%$ (CHP+HDP) \\
\hline
\end{tabular}

Source: Habertürk (2007) and Hürriyet (2018)

\section{Government}

The 'Sévres Syndrome' both within the Turkish public and among Turkish politicians indicates a fear of division by both internal and external enemies resurrecting the defunct Sévres Treaty (Guida, 2008; Nefes, 2013; Y1lmaz, 2006). It delegitimizes the West and fuels mistrust against Western states; therefore, it dictates Turks not to 'enter into economic, political and cultural pacts and alliances with the Western world' (Y1lmaz, 2006, p. 12). Nationalism fueled with this 'siege paranoia' long helped Turkish political actors stigmatize the EU accession process as a threat to the territorial and political integrity of Turkey (Guida, 2008; Y1lmaz, 2011). The 'Sévres Syndrome' was primarily reflected into the discourses of Turkish opposition parties aiming to gain the favor of the electorate against the government (Göçek, 2011; Nefes, 2013; Y1lmaz, 2011). The AKP, from its foundation, refrained from exhibiting the 'Sévres Syndrome' as it adamantly pioneered Turkey's pro-EU reform process since 2002. The AKP government has been considered by many in the scholarly literature immune to the 'Sévres Syndrome', since it was praised as a liberal force for Turkey shaking the foundations of the ancien régime which instilled the fear of division and hatred against Europeans (Guida, 2008; Kirişci, 2006; Nefes, 2013; Yavuz, 2009). The party was particulary depicted as a 'conservative globalist', which successfully mobilized the masses to achieve democratization through EU membership (Öniş, 2007). It was also praised as the bringer of Kantian peace to Turkey that had long been struggling with internal conflicts (Kirişci, 2006).

On the other hand, others in the scholarly literature view this pro-EU venture primarily as a strategic endeavour to help the AKP gain leverage over the Kemalist establishment through the EU's empowerment, even though the party and its electorate largely remain pro-Islamic with a potential to exhibit the 'Sévres Syndrome' (Baudner, 2012; Çınar, 2008; Öniş, 2010; Saatçioğlu, 2010; Saatçioğlu and El Basani, 2013). Despite its highly vivid pro-EU political stance, the AKP government actually admitted the cultural difference of Turks from Europeans, especially, through the Alliance of Civilizations (AoC) project. It was introduced as a United Nations initiative led by the Spanish and the Turkish governments in 2005 with the aim of diminishing hostility and promoting harmony among nations and cultures of the world, and preventing polarization between two conflicting civilizations; the West and the East (Gülmez, 2018, p. 434). The AKP's joint AoC venture helped consolidate Turkey's image as bridge between the East and the West while emphasizing its Oriental identity. In response to Samuel Huntington's famous 'Clash of Civilizations' thesis, the AKP contributed to the development of 
the AoC as a counter thesis, which, however, served to confirm the separation of the Western and the Eastern Civilizations based on cultural and religious differences, and thus, as a predominantly Muslim country, Turkey's place in the East. Through the AoC, the AKP nevertheless framed the West as a 'positive other' of the Muslim world, i.e. a potential partner to work towards international peace and stability through inter-cultural dialogue. According to İçener and Çağliyan-İ̧ener (2011), the AoC helped the AKP gain a cosmopolitan rhetoric in its foreign policy which was particularly instrumental to convince the EU for the initiation of Turkey's accession negotiations.

However, after the suspension of the accession process in 2005, the AKP government abandoned its existing European policies entirely and instead exhibited the 'Sévres Syndrome' both in its discourses and actions. Once a discursive tool for opposition politics, the 'Sévres Syndrome' has become an official policy line of the Turkish government through which the party officials explicitly frame Europe as a threat to Turkey's independence and stability, i.e. a 'negative other'. Europe is often stigmatized by government officials for 'being ruled by Islamophobic and anti-Turkish elites who wish to curb Turkey's economic growth and political clout in its neighbourhood' (Buhari-Gülmez, 2018).

Especially, following the eurozone crisis, European political discourses and actions against Turkey's EU accession triggered strong reaction from the Turkish government. The French government decided to block several negotiating chapters on Turkey, and the French and German leaders defended privileged partnership for Turkey instead of full membership. These actions, to a great extent, contributed to the eurosceptic turn in the AKP's EU policy since the AKP leadership for the first time went so far to characterise those leaders as 'fascists' (Erdoğan, 2011). Europe has no longer been considered the lingua franca of the AKP's political discourses $^{3}$, as the EU has lost its prominence in Turkey's political agenda (Alpan, 2014). In its 2011 election manifesto, the ruling party relagated Turkey's EU accession to a secondary place as one aspect of Turkey's 'multidimensional' foreign policy vision strengthened by its 'historical legacy, geo-political location and new dynamics of the globalising world' (Balkır and Eylemer 2016, p. 37).

The disillusionment with the EU then led the AKP officials to seek alternative partnerships instead of Europe. In an interview in 2013, Ali Şahin, the AKP deputy for Gaziantep and a member of the Parliamentary Committee on EU Harmonization, revealed Turkey's future plan, namely, 'The Middle East without borders' which aims to establish something similar to the EU in the Middle East by dismantling borders in the region arbitrarily drawn by the West (Gülmez, 2014, p. 230). In another interview, Mustafa Elitaş, the AKP deputy for Kayseri and the Deputy Chairman of the AKP's Parliamentary Group, highlighted 'alliance with Russia' as a very strong alternative to the EU which lost its credibility in Turkey (Gülmez, 2014, pp. 230-231).

The AKP's critical stance over the EU particularly intensified after the anti-government Gezi protests in the summer of 2013. The Gezi constitutes a turning point in the sense that the AKP government for the first time outspokenly exhibited the 'Sévres Syndrome' in its discourses. The party officials stigmatized the protests as an attempt, stimulated by foreign

\footnotetext{
${ }^{3}$ According to Alpan (2016, pp. 24-25), the EU is now only relevant for Turkish politics as a justification device, for the government often uses 'Europe as a partner in crime' to justify its authoritarian practices citing similar cases in European countries.
} 
powers, to overthrow a democratically elected government and explicitly charged the EU with supporting the protesters (Günay and Dzihic, 2016, p. 542).

The European Parliament (EP) issued a resolution condemning the AKP government's handling of the demonstrations and called on the government to 'put an end to its authoritarian style of governing' (European Parliament, 2013, p. 4). The officials of the European Commission stated that the Commission would prepare its 'toughest' progress report on Turkey criticizing the government's authoritarian response to the Gezi demonstrations (Hürriyet Daily News, 2013). The AKP officials dismissed the EU officials' criticisms as 'unfounded' and accussed the EU of acting as a 'partner in crime' (Alpan, 2016; Aydın-Düzgit, 2016).

In Erdoğan's speeches, the EP in particular, was dismissed as 'uninformed about Turkey', 'powerless/having no authority on Turkey', 'dishonest' and 'insincere' (Aydın-Düzgit, 2016, p. 52). Erdoğan declared publically that he would not recognize any decision taken by the EP over the Gezi protests (Y1lmaz, 2016a, p. 97). He even stressed his government's enthusiasm for Turkish membership to the Shanghai Cooperation Organization instead of EU membership (Dikici Bilgin, 2017, p. 204). The AKP government then renounced its observer status in the European People's Party and joined the ranks of the eurosceptic Alliance of European Conservatives and Reformists officially revealing its eurosceptic standing and stepping away from the European political mainstream (Tezcan and Aras, 2015, pp. 24-25; Wódka, 2016, pp. 303-304).

Euroscepticism widely observed in the government's discourses also penetrated into its actions from the Gezi events onwards reversing the pro-EU reform process in numerous policy areas including democratization, human rights, and freedom of media, amongst others especially (Aydın-Düzgit, 2016; Balkır and Eylemer, 2016; Boşnak, 2016; Onursal-Beşgül, 2016; Saatçioğlu, 2016; Soyaltın-Colella and Akdeniz-Göker, 2019; Yılmaz, 2016a; Yılmaz, 2016b). The government has even merged the Ministry of European Union with the Ministry of Foreign Affairs. This Eurosceptic policy turn has recently been scrutinized in the scholarly literature under the name of the 'de-Europeanization' of Turkey to denote the radical shift in the Turkish government's domestic policies 'in contrast to the EU demands for accession' since 2011 (Y1lmaz, 2016a, p. 87). The term has been popularly discussed in the scholarly literature to emphasize the erasure of Europe/the EU from Turkish political discourses and actions (Alpan, 2016; Aydın-Düzgit, 2016; Balkır and Eylemer, 2016; Boşnak, 2016; Onursal-Beşgül, 2016; Saatçioğlu, 2016; Yılmaz, 2016b).

After the Gezi, the Turkish government drew a clear line through a 'new Turkey vs old Turkey' discourse to distance Turkey from the EU. For instance, Erdoğan, dismissing the EU's ciriticisms of deteriorating freedoms in Turkey, claimed that those who point fingers at Turkey must understand that they are no longer facing the old Turkey (Yaka, 2016, p. 150). The prevailing scholarly literature corroborates with this argument and highlights that the AKP elite deliberately invented a 'new Turkey' discourse redefining Turkish identity along religious lines as detached from and morally superior to Europe (Aydın-Düzgit, 2016, pp. 55-56; AydınDüzgit, 2018, p. 22). At the same time, Europe has been categorized as Turkey's other and represented in the ruling party's discourses as 'unwanted', 'discriminatory', 'different' and 'inferior' (Aydın-Düzgit, 2016; Aydın-Düzgit, 2018; Alpan, 2016; Balkır and Eylemer, 2016). Aydın-Düzgit (2018, p. 22) particularly contends that the othering of Europe through the claims of moral superiority and the Sèvres syndrome had long been present in Turkey, but those 
representations became the official discourse of Turkey during the AKP government with a strong reference to the Ottoman past.

Langan (2017, p. 1400) derives a similar conclusion arguing that the loss of credible EU incentives prompted the AKP leaders to construct a new altruistic identity for modern Turkey, namely 'virtuous power Turkey' carving out a distinct international role 'in juxtaposition to the machinations of an 'imperial' EU'. That's why, according to Langan (2017, pp. 1400-1401), the AKP elite often referred to the glory and the legacy of the Ottoman past to articulate 'a uniquely Turkish moral mission in global affairs' and 'reassert Turkish policy autonomy on a global level vis-à-vis Europe'. This newly engineered Turkish identity, in Langan's (2017, pp. 1401-1411) view, serves not only to present Turkey as a benevolent and altruistic nation to the non-Western countries, but also contributes to the creation of a European other which is 'imperial', 'neocolonial', 'aggressive' and 'self-interested', hence unreliable.

The Turkey-EU refugee deal in 2015 and the coup attempt in 2016 only contributed to the aggravation of the AKP government's Eurosceptic discourses and actions. As a joint response to the mass refugee exodus to Europe due to the Syrian civil war, the EU chose to strike as deal with Turkey on the protection of borders and limitation of refuge entry into the EU. ${ }^{4}$ Turkey agreed to the readmission of refugees in return for financial assistance up to 3 billion euros and a facilitated visa scheme for Turkish nationals. The EU presented the refugee deal as part of its commitment to 're-energize' Turkey's accession process (İçener, 2016, p. 73). This deal therefore raised hopes that the refugee crisis could bring about a 'strategic rapprochement' between Turkey and Europe (Buhari-Gülmez, 2016). However, the EU's denial of visa-free travel to Turks due to Turkey's persistent refusal to change its anti-terror law proved the hopes for a rapprochement short-lived and re-ignited the AKP's Eurosceptic discourse (İçener, 2016, p. 74). For instance, Turkish Minister of Interior, Süleyman Soylu, threatened to send Europe ' 15.000 refugees each month' just a couple of days before the first anniversary of the TurkeyEU Refugee deal (Kaya, 2020, p. 20).Similarly, Erdoğan threatened to 'open the gates' to unleash refugees into Europe if the EU does not fulfil its obligations arising out of the refugee deal (Timur and Nordland, 2016).

The failed coup in 15 July 2016 constituted another breaking point in Turkey-EU relations aggrandizing the AKP's harshening tone against the EU. A religious cult led by a preacher named Fettullah Gülen which had long infiltrated into the Turkish state bureaucracy attempted a coup in the evening of 15 July 2016 through its aspects within the Army and the Police. The Turkish Army along with the masses who took the streets prevented the coup attempt. However, the immediate reaction of the EU and the member states was rather sceptical as they did not condemn the coup attempt outright and then criticized the AKP government for the ill-treatment of those directly or indirectly involved in the Gülenist putsch (İçener, 2016; Tasch, 2016). The EP called for the suspension of Turkey's EU accession talks indefinitely due to the rising authoritarian practices in Turkey following the failed coup (Toksabay and Karadeniz, 2017). Erdoğan responded in disappointment that they expected Europe to show solidarity with Turkey just like Turkey had showed solidarity with Europe after the terrorist attacks to Charlie Hebdo, a French political magazine (Tash, 2016). He claimed that the West abandoned them 'contradicting the values it is defending' (Semo, Jégo and Ayad, 2016). He even blamed Europeans for collaborating with the coup plotters: 'Those who we imagined to be

\footnotetext{
${ }^{4}$ For a detailed analysis on the refugee deal, see Benvenuti (2017).
} 
friends are standing by the coup plotters and by the terrorists...This coup attempt has actors inside Turkey, but its script was written outside' (Business Insider UK, 2016). The tension rose again after Germany denied Turkish demand for the extradition of Adil Öksüz, one of the top suspects behind the coup attempt, and this escalated the crisis in bilateral relations even further (Kaya, 2020, p. 20). In response, Erdoğan went so far to advise German Turks not to vote for the political parties critical of the Turkish government (Kaya, 2020, p. 21).

Since the failed coup attempt, the party started to explicitly blame the EU for collaborating with the enemies of Turkey including the PKK and the Gülenists. During the campaigns for the 2017 Presidential referendum, the pro-AKP news outlets framed the EU as a supporter of the NO campaign co-organized by the actors threatening Turkey's stability including the PKK, the Gülenists and the CHP (Birgün, 2017; Takvim, 2017). Takvim newspaper (2017) even accused the European supporters of a No vote in the referendum of forming an 'unholly alliance of Europe' to weaken Erdoğan and his government. Moreover, Erdoğan often used an othering discourse to discredit both opposition and Europe during the referendum campaign. Reminding the recent crisis between the Dutch and the Turkish governments ${ }^{5}$, Erdoğan dismissed the CHP, the main opposition party as 'the Dutchman among us' due to its persistent objection to the Presidential system (Birgün, 2017). Besides, Erdoğan charged the German and Dutch governments with 'Nazism' since they did not approve Erdoğan's demands to conduct presidential election campaign in their soil (Kaya, 2020, p. 20).

Moreover, the AKP officials often hold the West responsible for political and economic crises in Turkey. Most recently, they have blamed Western speculators for the serious devaluation of the Turkish Lira (Buhari-Gülmez, 2018). However, the assignment of McKinsey, an American firm, as the advisor for Turkey's economic policies contradicts the government's outspokenly anti-Western discourse and poses the question whether the government's West-free policy line is rather strategic ${ }^{6}$.

\section{Opposition}

The prevailing literature offers two main explanations for the opposition's Eurosceptic discourses. One explanation concentrates on the historical and ideological roots of scepticism towards Europe and the West with a particular reference to the 'Sévres Syndrome' (Y1lmaz 2011), while the other emphasizes the usage of Euroscepticism as a strategic tool to discredit the government in public eye (Celep 2011; Gülmez, 2013b).

The main opposition party, the CHP could be argued to have exhibited both tendencies in its EU policy. Its sceptic rhetoric against the EU-led reform process from 2002 onwards

\footnotetext{
${ }^{5}$ The crisis began when the Dutch government refused to permit the AKP officials to conduct referendum campaigns in the Netherlands in early March 2017 and the tension intensified after the expulsion of Mrs Fatma Betül Sayan Kaya, Turkish Minister of Family in 11 March 2017. The AKP government conducted a smearing campaign charging the Dutch government with Islamophobia, Fascism and Nazism. In response, the Dutch government formally withdrew its ambassador to Turkey and decided not to accept a new Turkish ambassador in the Hague. The crisis lasted until July 2018 when the Foreign Ministers of both countries held meetings to decrease tension. For a detailed information, see BBC (2017), BBC (2018), CNN TURK (2017) and Hürriyet Daily News (2018).

${ }^{6}$ The government was forced to cancel the deal with McKinsey after suffering harsh criticisms. For more detail, see Gümrükçü (2018).
} 
reflected a fear of division associating the reforms with the provisions of the infamous Sévres Treaty. The Eurosceptic discourses have also been used to demonize the government in public eye. As the oldest political party in the Turkish Republic, the CHP celebrated EU membership as a 'national cause' for Turkey (Baykal, 2003). After the 2002 elections, however, the CHP's pro-EU stance has remained at the rhetorical level since it adopted a highly critical stance towards the EU and opposed many aspects of the EU-led reform process in Turkey with the preoccupation to protect the integrity of the Turkish Republic. Especially, the EU-led reforms on minority rights were strongly criticized as reminiscent of the Sévres Treaty. For instance, party officials claimed that a similar provision concerning the rights of minority foundations was already included in Article 140 of the Sèvres Treaty (TBMM, 2008a).

According to Öniş (2010, p. 361), the CHP's support for EU membership stemmed from its quest to consolidate the secular and modern character of Turkey and prevent the Islamisation of Turkish society, but the accession process empowered the pro-Islamic AKP. During this period, the party leader Deniz Baykal transformed the CHP into a nationalistic party observed through the populist change in the party's EU discourses (Celep, 2011; Öniş, 2007; Y1lmaz, 2011). Accordingly, there emerged a paradoxical political climate in Turkey whereby the proIslamic AKP established itself as a vigorous supporter of EU accession, while the 'Social democrat' CHP turned out to be a 'defensive nationalist' resisting the EU-led reform process (Öniş 2007, p. 247).

Kemal Kılıçdaroğlu, who replaced Baykal in May 2010 as the party leader, aimed to erase the traces of Baykal's hardline and highlight the CHP's social democratic identity by abandoning Baykal's critical stance against the EU (Baudner, 2012; Celep, 2011). He aimed for a clean slate in Turkish-EU relations emphasizing the CHP's renewed enthusiasm for Turkey's EU accession. Therefore, leadership change helped trigger a transformation in the CHP's EU discourses from populist eurocepticism to euro-enthusiasm (Gülmez, 2013a). However, K1lıçdaroğlu was not the only factor in the CHP's renewed pro-EU rhetoric. Actually, the CHP had already initiated a pro-EU turn in its actions under Baykal who, for instance, ordered the opening of a Brussels office of the party in 2008 to closely monitor the Turkey-EU deliberations and paid a visit to Brussels, Berlin and London to convince Europeans that the CHP was actually a pro-EU political party.

The swift Euro-enthusiasm in the CHP's discourses could be argued to have stemmed, to a great extent, from the party's strategic positioning vis-a-vis the changing EU approach of the AKP government. The CHP's apparent withdrawal from euroscepticism curiously coincided with the rising euroscepticism in the AKP. Therefore, when the AKP took remarkable steps towards EU accession, the CHP adopted a Eurosceptic rhetoric to dismiss the EU-led reforms, and after the AKP adopted a Eurosceptic discourse, in response, the CHP tended to reflect a more pro-EU stance (Gülmez, 2013b). Especially, the suspension of the accession negotiations, while driving the AKP away from the EU, provided the main opposition with an opportunity to fill in the gap by assuming the role of the pro-EU force in Turkey. In numerous occasions, Party officials stigmatized Erdoğan as the sole responsible for the problems in Turkey's EU accession, and claimed to revitalize bilateral relations under the CHP government (Gülmez, 2013a).

The CHP's strategic pro-EU turn in response to the AKP's euroscepticism was particularly observed during the Gezi protests. The party not only actively supported the 
protests to gain a popular ground against the AKP government, but also assumed the role of a mediator to push for a reconciliation between Turkey and the EU in order to keep Turkey's hopes for EU accession alive. Kılıçdaroğlu, for instance, wrote a letter to German Chancellor Angela Merkel urging her not to block Turkey's EU accession talks in the face of the brutality of police forces against the protestors during the \#Occupygezi movement (Kaya, 2017, p. 130). He argued that the Gezi protests revealed the true potential of Turkey's young generation who demanded democracy, freedom and respect for rule of law (Hürriyet, 2013). Therefore, punishing the AKP government by denying Turkey's membership would also mean undermining this potential, Kılıçdaroğlu claimed (Ibid). Kılıçdaroğlu also wrote a letter to Dutch Prime Minister Mark Rutte demanding the EU not to turn its back on Turkey (Cumhuriyet, 2013).

The CHP persisted in its pro-EU rhetoric and desire for assuming a mediatory role between Turkey and the EU after the failed coup attempt. Against the EP's advice for the suspension of Turkey's EU accession negotiations, Kılıçdaroğlu called on all the EU institutions and member states not to abandon Turkey (Cumhuriyet, 2016). Similar to his Gezi statements, he announced that the EU should not punish entire Turkey for the controversial acts of one person, meaning Erdoğan (Ibid).

The junior opposition party, the MHP, formed in 1969 to spread Turkish nationalism and 'ward off the communist threat', represents the far right in Turkey (Heper and İnce, 2006, p. 873). Europeanization has never been an objective for the MHP since party officials rather consider Turkey-EU relations as 'a matter of primarily economic and security-related alliances' (Canefe and Bora, 2003, p. 144). Therefore, the party remains strongly opposed to European integration through a complicated accession process (Avc1, 2011). Especially, its long-standing dismissal of Turkey's Kurdish problem and assumption that the EU-led reforms granting more rights to Kurds will ensure the partition of Turkey mainly structure its critical stance towards Turkey's EU accession process (Avc1, 2011, p. 441; Öniş, 2003, p. 45). The discourses of party officials against minority rights reforms were highly reflective of the 'Sévres Syndrome'. According to them, through the reform, Europeans succeeded in taking the revenge of their defeat in the Turkish war of independence by making Turks accept some of the key provisions of the Sèvres Treaty (TBMM, 2008a). Similarly, the MHP raised strong criticisms against the EU-led reform facilitating foreign land ownership and accused the government of selling the hard-won Turkish lands for economic gain. Party officials even claimed that the reform proposals were actually drafted and introduced by 'foreign powers' to buy off Turkish territories (TBMM, 2008b).

It could be argued that it was primarily the ultra-nationalist ideology that shaped the MHP's EU policy. However, Avc1 (2011, p. 445) reminds that the magnitude of the party's eurosceptic tone is conditioned by whether it is in government or opposition. The MHP actually adopted a softer stance towards EU membership when in government (1999-2002), whereas it demonstrated a hard-line stance when in opposition (Ibid). The MHP's most visible eurosceptic discourse when in government was primarily observed against certain EU-led reforms including the freedom of speech and the abolition of the death penalty in order to protect the Turkish state against Kurdish separatism (Avc1, 2011, p. 440). Nevertheless, the party's euroscepticism is not directly linked to the AKP's EU stance. The controversial EU discourses of the MHP remained intact after the suspension of the accession process. Therefore, unlike the CHP, the party's 
euroscepticism is rather unaffected by the eurosceptic turn in the AKP government's discourses and actions.

Just like the AKP government, the MHP holds the EU responsible for political crises in Turkey including the coup attempt. Devlet Bahçeli, the party leader blamed the EU for turning a blind eye to the gravity of the coup and focusing on the ill-treatment of the coup plotters in custody (Al Jazeera, 2017). He argued that Europeans should have congratulated Turkey with standing ovation for its heroic victory against the coup plotters (Hürriyet, 2017). Therefore, according to Bahçeli, the failed coup revealed the ugly face of Europe, since many European countries shelter Gülenists along with PKK terrorists (Cumhuriyet, 2018). Bahçeli even equaled the failed coup to the 'Crusades' claiming that the West was behind the coup attempt (Sabah, 2017). Although the MHP chose to stand in partnership with the AKP government in general elections, party officials also criticized the AKP for signing a refugee deal with the EU. Bahçeli blamed the AKP government for weaponizing the refugees to extract privileges from Europeans (Hürriyet, 2017).

The MHP today still exhibits 'Sévres Syndrome' in its dicsourses. Party officials charge the EU with having a 'Crusade mentality' evidenced by the rising Islamophobia and antiTurkish sentiments across Europe (Cumhuriyet, 2018). Bahçeli even claims that the EU aims to put a shroud on Turkey: 'either we will wear the shroud envisioned by the EU for us, or we will tear it apart' (NTV 2018). Stressing that the EU has never been a matter of life and death for Turkey, Bahçeli reminds that Turkey is not a failed state deprived of sovereignty and forced to remain within the EU's orbit (Cumhuriyet, 2018). In his view, Turkey has the capability to determine its own fate independently from the EU: 'Those who treat Turkey as a 'sick man' will be drowned in their nonsense' (Ibid).

\section{Public Opinion}

Studies on Turkey indicate a limited impact of public opinion on policy-making especially regarding Turkey's EU accession (Güneş-Ayata, 2003; Spiering, 2007; Y1lmaz, 2009). Turkish public opinion rather mirrors political parties' views (Aydın-Düzgit, 2018). For instance, during the zenith of the AKP's pro-EU activism between 2002 and 2005, its electorate tended to favour the AKP's pro-EU policies, although the majority of AKP voters was critical of the EU associating it mostly with Christianity (Spiering, 2007, p. 177; Y1lmaz, 2009, pp. 89). Similarly, constituting one of the most Europhile of Turkish society, the CHP electorate however mostly supported its Eurosceptic policies (Y1lmaz, 2011, p. 202-204).

Therefore, fluctuations in public support for or opposition to the EU and Turkey's EU membership are in direct resonance with (positive or negative) change in Turkish politicians' EU rhetoric. Accordingly, Eurobarometer surveys indicate a remarkable decline in Turkish public support for EU membership from 60\% in 2004 to 35\% in 2012 highly reflective of the disillusionment of Turkish politicians with the EU after the curtailment of the accession negotiations (Dikici Bilgin, 2017, p. 192). "The feeling of disappointment and apathy" with the suspension of Turkey's EU accession process has been particularly highlighted in the literature as the main motivation behind such a decline (Yaka, 2016, p. 150).

Moreover, Dikici Bilgin (2017, p. 192) claims that this sharp decline stems from the strengthening conviction among Turkish people that Turkey will not benefit from being a 
member of the European Community, but it will rather be harmed by it. High economic performance of Turkish economy by 2012 might have prompted Turkish public to believe that Turkey would no longer be economically dependent on the EU (Dikici Bilgin, 2017, p. 203). Similarly, Keyman and Aydın-Düzgit (2013, p. 279) argue that Turkey's economic development and the AKP's rising electoral popularity helped the AKP electorate mirror the self-confidence of the AKP government which looks down on the EU, and believes that Turkey does not need the EU anchor, whereas the EU needs Turkey.

Eurobarometer surveys especially from 2012 onwards ask questions to measure the EU's image in the eyes of Turkish public rather than the level of public support for EU membership. Accordingly, the figures indicate that in the aftermath of the Gezi protests, the EU's image in public eye decreased considerably, positive votes only accounting for $20 \%$, while 'don't knows' around $30 \%$. Throughout 2014, on the other hand, the positive image of the EU rose to an average of $40 \%$ while the negative remained only around $25 \%$. Throughout 2015 , the EU's image became highly positive up to $60 \%$ approval from the Turkish public reflecting the public enthusiasm for the EU in response to the EU-Turkey refugee deal. However, in autumn 2016, the positive votes went down to $35 \%$ indicative of the public resentment against the EU's approach to the coup attempt. Nevertheless, even then, the negative votes against the EU remained at $17 \%$, while it was the neutral votes that rose to $42 \%$ in autumn 2016 . This clearly shows that even though certain breaking points in Turkish politics remarkably decrease the positive image of the EU in public eye, this does not automatically translate into a total negative image for the EU. In moments of crisis, Turkish public is inclined to remain either neutral or undecided on whether the EU is good or bad for them. Equally striking is that during the turbulent times between 2014 and 2018, the positive image of the EU mostly revolved around $45 \%$, while its negative image never went above $26 \%$.

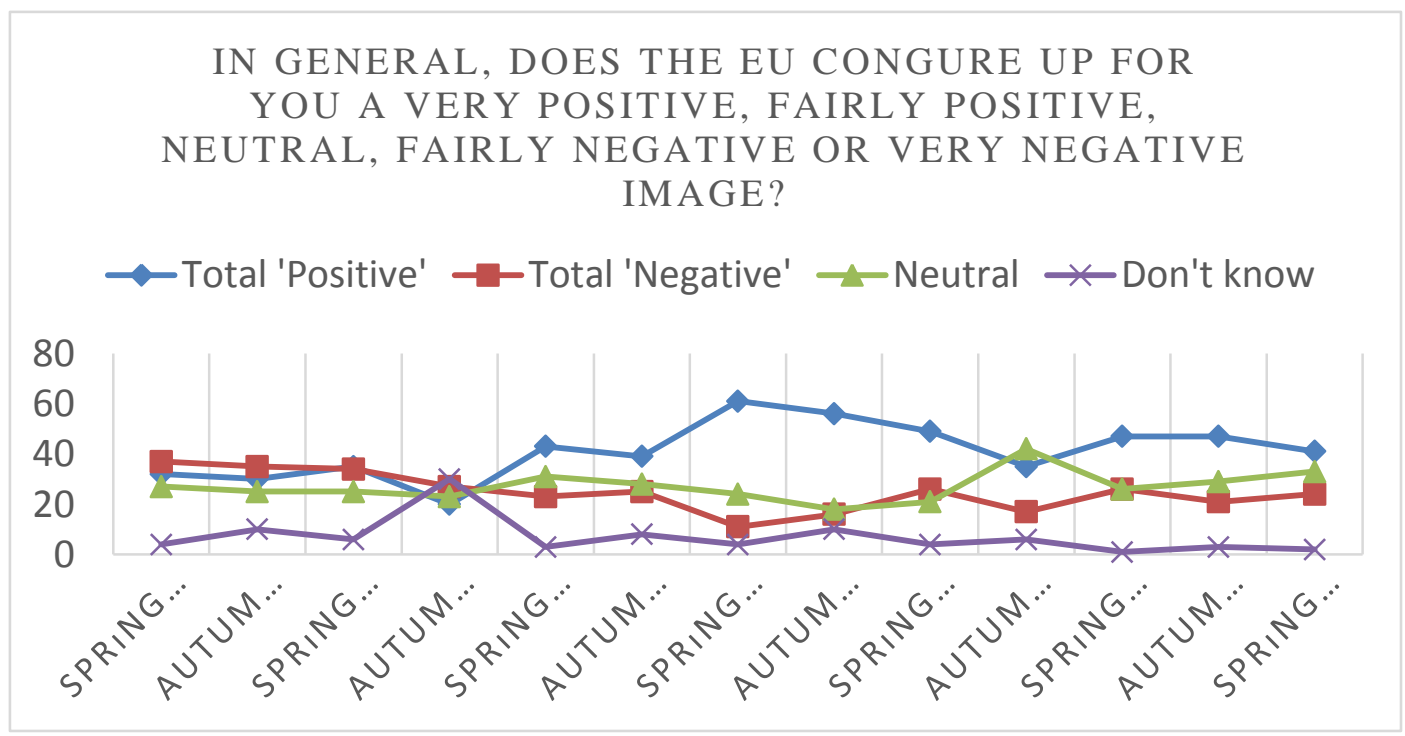

Figure 1: The EU's Image in the Eyes of Turkish Public (2012-2018)

Sources: Standard Eurobarometer, 77-89

How is the public approval rate of the EU translated into support or opposition to Turkey's EU membership? In order to find a solid answer to this question, the article compares 
the findings of Kadir Has University's "Research on Social \& Political Trends in Turkey" with those of the Eurobarometer surveys. According to the Kadir Has polls, the post-2012 period reveals rather a split within the Turkish society, which is reflected into public preferences towards Turkey's EU membership. The polls confirm an almost even split within the Turkish society towards EU accession, but they also highlight that certain breaking points such as the Gezi and the coup attempt lead to fluctuations in public preferences. Accordingly, support for Turkey's EU membership remains rather steady in 2012 and in 2013 with 50,4\% and 51,8\%, respectively, slightly over the opposing votes. In comparison to the Eurobarometer findings, however, the polls indicate a relatively high ratio of public support for EU membership, although the EU's positive image remains as low as $20 \%$ in 2013.

The public support for EU membership dramatically rises to 71,4\% in 2014 in the Kadir Has polls, while the public approval ratio of the EU also rises to $40 \%$ in the Eurobarometer survey. According to Kaya (2017, p. 129), the increase in public support towards the EU is directly linked with the Gezi events, which exacerbated the longing within the Turkish society for "democracy, accountability, transparency, freedom of speech and the rule of law, the values of which the EU is strongly believed to have". Kaya (2017, p. 126) claims that the "Occupy Gezi' movement contributed to the transformation of Turkish civil society from Eurosceptic to pro-European. Especially, such a discursive change was visible among the secular civil society actors such as the Confederation of Progressive Trade Unions (DISK); and Confederation of Public Labourer's Unions (KESK) along with secular newspapers including Cumhuriyet and Sözcü known for their vocal criticisms of the EU (Kaya, 2017, p. 131).

Compared to 2014, the Kadir Has polls indicate a relative decline in Turkish public support for EU accession $(65,1 \%)$ in 2015, yet it is still way above the opposition (34,9\%). On the other hand, the positive image of the EU in the same year rises to a record level of $61 \%$. According to the scholarly literature, the Syrian refugee crisis and the reluctance of EU member states to host refugees generated Eurosceptic reactions within the Turkish public (Aydın-Düzgit, 2018, p. 29), yet the EU-Turkey deal on the status of refugees in return for the EU's promise for visa liberalization to Turkish nationals helped re-gain public interest towards EU membership and increase public approval of the EU (Benvenuti, 2017, p. 6). 


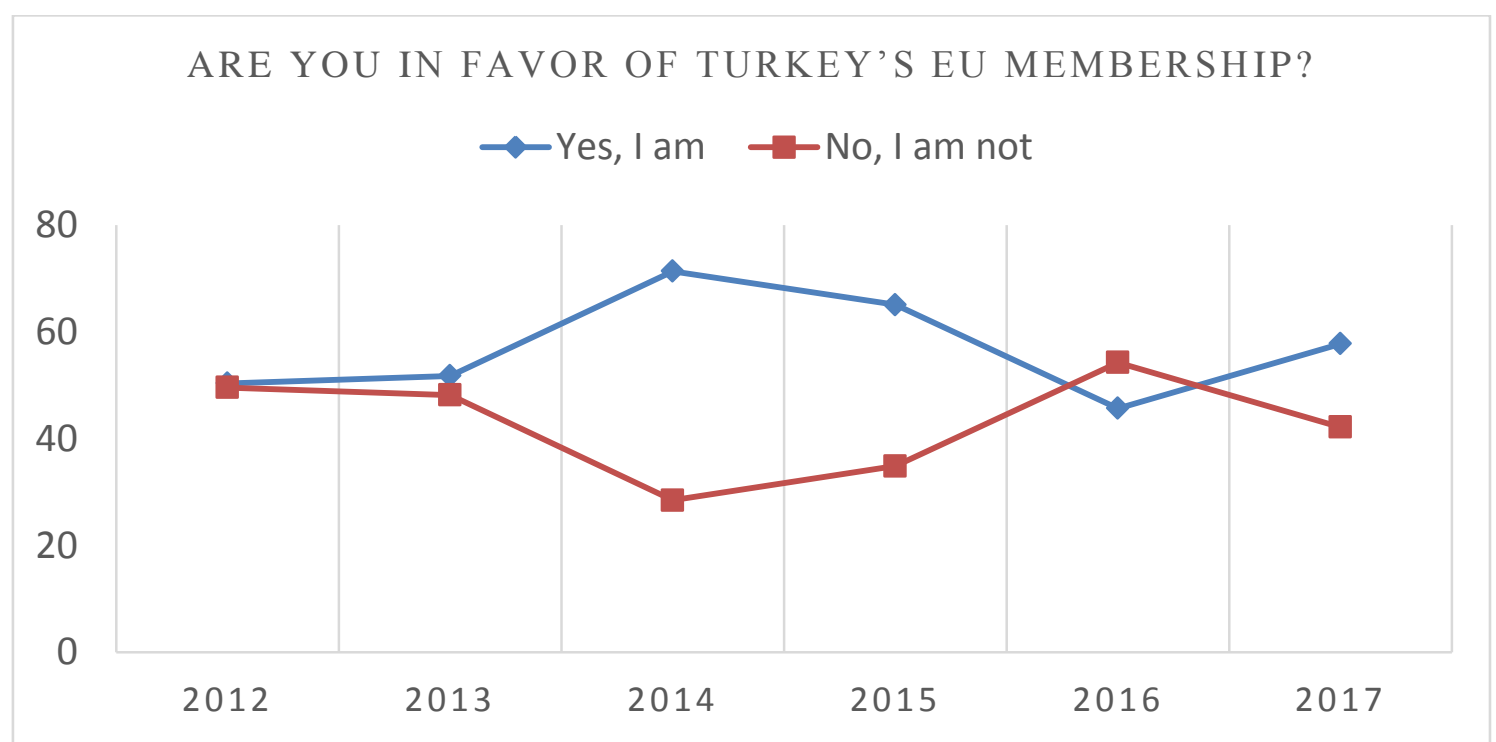

Figure 2: Turkish Public Support for Turkey's EU Membership (2012-2017)

Source: Research on Social \& Political Trends in Turkey, Center for Turkish Studies, Kadir Has University, 31 January 2018.

The 2016 figures, however, indicate a sharp decline in public support to $45,7 \%$ which is explained in the literature by the Turkish disappointment with the EU's response to the 15 July coup attempt (İçener, 2016, p. 75). The Eurobarometer survey highly corroborates with these findings as it also indicates a decrease in the public approval rate of the EU as low as $35 \%$. Nevertheless, what is remarkable here is that even in the face of an intensive political crisis such as the coup attempt, Turkish public support for EU accession remains close to $50 \%$ indicative of a political split within Turkish society.

Aydın-Düzgit's (2018) recent study reveals the impact of political divisions upon the public representations of the EU. Accordingly, the AKP's representation of the EU as Turkey's other remains highly influential among its electorate who mirrors the government's discourses depicing the EU as morally, democratically and economically inferior to Turkey (Aydın-Düzgit, 2018, p. 28). Especially, criticizing the reluctance of the EU to accept Syrian refugees, the AKP electorate rather adopts a post-colonial discourse claiming to side with "the oppressed", i.e the refugees, against the oppressors, i.e. the EU (Aydın-Düzgit, 2018, p. 29). The government's negative discourse on the EU, on the other hand, translates into positive representations of the EU within the opposition electorate. Criticizing the backsliding in Turkey's democracy and freedom under the AKP rule, especially the opposition voters embrace the EU as a way out of this crisis, as "the bearer of democracy and human rights" and "a normative anchor for Turkey" (Aydın-Düzgit, 2018, pp. 26-27).

\section{Conclusion}

This article aimed to revisit the state of euroscepticism in Turkey with a particular focus on the shifting dynamics of euroscepticism at governmental, opposition and public level. Accordingly, eurosceptic turn in Turkish government is remarkable. Once highlighted as 'the most outspokenly pro-EU party in Turkey', the AKP has now become the most outspokenly eurosceptic Turkish political party (Başkan Canyaş and Gümrükçü, 2015, p. 147). Having long 
pioneered Turkey's europeanization, the AKP grew increasingly eurosceptic after the suspension of the accession process. The EU in the AKP's discourses drastically changed from a potential partner to a potential threat, i.e. from 'positive other' to 'negative other', highly reflective of the 'Sévres Syndrome' to which the AKP was long considered immune. Especially after the Gezi protests and the failed coup, de-europeanization dominated the AKP's domestic and foreign policy indicating that euroscepticism not only conquered the party's discourses, but penetrated into its actions as well. What is even more remarkable is that the AKP adopted more than a eurosceptic approach; it rather embraced a vengeful discourse against the west as a whole. The party carved out a distinct oriental identity for Turkey allegedly superior to Europe, and demonized the west through a post-colonial rhetoric (Aydın-Düzgit, 2018; Langan, 2017). However, this antagonistic discourse only serves to isolate Turkey further and decreases its credibility in the west. If one day the AKP decides to go back to its old pro-EU rhetoric, party officials might not be able to find the old EU where they left off.

Euroscepticism in Turkish opposition is a double-edged sword. While the CHP mostly uses eurosceptic discourse as a strategic tool to gain ground against the AKP in domestic politics, the MHP's euroscepticism is rather structured by its ultra-nationalistic ideology mostly devoid of party competition. The excessive exhibition of the 'Sévres Syndrome' in the CHP's discourses does not necessarily indicate an ideological euroscepticism. The CHP rather uses it to gain legitimacy in public eye. This is so because the CHP abandons its eurosceptic discourse, when the AKP abandons its pro-EU rhetoric. This pro-EU turn also proves to be more strategic than genuine especially when party officials revert to old eurosceptic discourse in response to the AKP's pro-EU deeds. For instance, the CHP quickly abandoned its criticism-free EU stance when the AKP took a step to develop bilateral relations especially in the face of the Syrian refugee crisis. Party officials strongly stood against the refugee deal between Turkey and the EU dismissing it as unethical and unacceptable. Kıliçdaroğlu even accused the EU of turning Turkey into 'Europe's concentration camp' (Sözcü, 2015). He insisted that Turkey should reject such offers even if the EU awarded Turkey with huge sums of money and visa liberalization, since the massive influx of refugees, unless prevented, would eventually distort the demographic homogeneity of Turkey (Ibid).

Y1lmaz (2011, p. 204) considered the CHP's future pro-EU turn as a possible game changer for Turkey-EU relations. However, the pro-EU turn under Kilıçdaroğlu hardly made any difference for Turkey's EU accession since it was more strategic and rhetorical than genuine. The CHP's EU rhetoric is mostly conditioned by how the AKP develops and changes its EU policy. Since the Baykal period, its EU policy is mostly reactionary, hence hardly credible.

On the other hand, the MHP remains the only major Turkish political party that persists in Euroscepticism. It is the only political party that consistently exhibited the 'Sévres Syndrome' associating EU membership with the distortion of Turkey's political sovereignty and territorial integrity. Its eurosceptic stance is to a large extent structured by its ultra-nationalist ideology which dictates the preservation of Turkish identity and sovereignty at all costs. Therefore, its eurosceptic stance is hardly influenced by the economic and political opportunities provided by the EU accession process. Moreover, its EU discourses are not conditioned by the changing EU rhetoric of either the AKP government or the CHP. During the zenith of Turkish-EU relations led by the AKP government, the MHP's eurosceptic discourses mostly aligned with the EU stance of the CHP. After the curtailment of the accession negotiations, we observed a strong 
alignment between the EU discourses of the AKP and the MHP. However, unlike its counterparts, the MHP has never abandoned its hard Eurosceptic stance persistently dismissing the EU accession as a threat to Turkish identity and sovereignty.

Regarding the state of euroscepticism in Turkish public opinion, it is safe to argue that Turkish public essentially reflects the views of popular political parties. When the AKP shifts from pro-EU activism to euroscepticism, the AKP electorate mirrors this eurosceptic shift referring to the discourses that the AKP officials use. The opposition voters also mirror their party's position, but they also secure a tendency to support Turkey's EU accession in response to the eurosceptic attitude of the AKP electorate (Aydın-Düzgit, 2018). This strategic positioning is reflected into the polls as an almost even split concerning the public support for Turkey's EU membership. Both government and opposition voters respond to critical developments such as the Gezi and the attempted coup resulting in fluctuations in public support for EU membership. Nevertheless, despite all political crises, as the Eurobarometer surveys indicate, at least $40-45 \%$ of the public continue to view the EU positively, and as the Kadir Has polls stress, an average of $50 \%$, either government or opposition electorate, persistently supports Turkey's EU membership.

Overall, strategic euroscepticism is popularly used by both government and opposition in Turkey to gain popularity in domestic politics. However, when eurosceptic, both the AKP and the CHP use such a strong anti-EU discourse in resonance with the 'Sévres Syndrome' as if their euroscepticism is guided by the hatred of Europeans. However, both parties are prone to abandon their pro or contra EU discourses when there is a shift in Turkey's political context. This renders their EU rhetoric less than credible in the eyes of the EU and might face resistance within the EU when they decide to revisit their eurosceptic stance. This opportunistic approach directly influences Turkish public who tends to shift its views towards the EU when their political party does. 


\section{References}

Al Jazeera. (2017). Bahçeli: Avrupa'ya ağır bir faturası olur [Bahçeli: It costs Europe gravely]. Retrieved from http://www.aljazeera.com.tr/haber/bahceli-avrupaya-agir-bir-faturasi-olur

Alpan, B. (2014). "Europe-as-hegemony" and discourses in Turkey after 1999: What has "Europeanisation" got to do with it?. Journal of Balkan and Near Eastern Studies, 16(1), 6885. https://doi.org/10.1080/19448953.2013.864184

Alpan, B. (2016). From AKP's "Conservative democracy" to "advanced democracy": Shifts and challenges in the debate on "Europe". South European Society and Politics, 21(1), 15-28. https://doi.org/10.1080/13608746.2016.1155283

Avc1, G. (2011). The Nationalist Movement Party's euroscepticism: Party ideology meets strategy. $\begin{array}{llll}\text { South European Society and Politics, } & \text { 16(3), }\end{array}$ https://doi.org/10.1080/13608746.2011.598359

Aydın-Düzgit, S. (2016). De-Europeanisation through discourse: A critical discourse analysis of AKP's election speeches. South European Society and Politics, 21(1), 45-58. https://doi.org/10.1080/13608746.2016.1147717

Aydın-Düzgit, S. (2018). Foreign policy and identity change: Analysing perceptions of Europe among the Turkish public. Politics, 38(1), 19-34. https://doi.org/10.1177/0263395717729932

Balkır, C. and Eylemer, S. (2016). Shifting logics: The discourses of Turkish political elites on EU accession. South European Society and Politics, 21(1), 29-43. https://doi.org/10.1080/13608746.2016.1147523

Başkan Canyaş, F. and Gümrükçü, S. B. (2015). Europeanization and political parties in Turkey. In A. Tekin and A. Güney (Eds.), The Europeanization of Turkey: Polity and politics (pp.145-161). London: Routledge.

Baudner, J. (2012). The Politics of 'norm diffusion' in Turkish European Union accession negotiations: Why it was rational for an islamist party to be 'pro-European' and a secularist party to be "anti-European". Journal of Common Market Studies, 50(6), 922-938. https://doi.org/10.1111/j.1468-5965.2012.02291.x

Baykal, D. (2003, 3 June). Baykal's speech in the CHP Parliamentary Group reunion. Turkish Parliament, Ankara.

BBC. (2017). Turkey-Netherlands row: Dutch warn citizens after Erdogan threat. Retrieved from https://www.bbc.com/news/world-europe-39254556.

BBC. (2018). Turkey-Netherlands row: Dutch ambassador withdrawn. Retrieved from https://www.bbc.com/news/world-europe-42943825.

Birgün. (2017). Erdoğan: Terör örgütleri ve ana muhalefet "hayır" diyor [Erdoğan: Terrorists and main opposition say "No"]. Retrieved from https://www.birgun.net/haber-detay/erdogan-terororgutleri-ve-ana-muhalefet-hayir-diyor-151415.html.

Benvenuti, B. (2017). The Migration paradox and EU-Turkey relations (Istituto Affari Internazionali Working Papers No. 17). Retrieved from http://www.iai.it/en/pubblicazioni/migration-paradoxand-eu-turkey-relations.

Boşnak, B. (2016). Europeanisation and De-Europeanisation dynamics in Turkey: The case of environmental organisations. South European Society and Politics, 21(1), 75-90. https://doi.org/10.1080/13608746.2016.1151476

Buhari-Gülmez, D. (2016, 5 October). Turkey’s relations with Europe are in flux following Ahmet Davutoğlu's resignation [LSE Blog]. Retrieved from http://blogs.lse.ac.uk/europpblog/2016/05 /10/turkeys-relations-with-europe-are-in-flux-following-ahmet-davutoglus-resignation/.

Buhari-Gülmez, D. (2018, 26 September). Why Turkey's currency crisis is deepening the rift between Ankara and the West [LSE Blog]. Retrieved from http://blogs.lse.ac.uk/europpblog/2018/ 09/26/why-turkeys-currency-crisis-is-deepening-the-rift-between-ankara-and-the-west/. 
S. B. Gülmez, "Rethinking Euroscepticism in Turkey: Government, Opposition and Public Opinion"

Business Insider UK. (2016). Erdogan: The West supports 'terror' and stands behind 'coup plotters'. Retrieved from http://uk.businessinsider.com/afp-turkeys-erdogan-accuses-west-of-supportingterror-coup-plotters-2016-8.

Canefe, N. and Bora, T. (2003). The Intellectual roots of anti-European sentiments in Turkish politics: The case of radical Turkish nationalism. Turkish Studies, 4(1), 127-148. https://doi.org/10.1080/714005725

Celep, Ö. (2011). The Republican People's Party and Turkey's EU membership. South European Society and Politics, 16(3), 423-434. https://doi.org/10.1080/13608746.2011.598358

CNN Türk. (2017). Erdoğan'dan Hollanda'ya sert tepki: Bunlar Nazi kalıntısı [Erdoğan's strong reaction to Holland: They are remnants of Nazis], [Video]. Retrieved from https://www.cnnturk.com/video/turkiye/erdogandan-hollandaya-sert-tepki-bunlar-nazikalintisi.

Cumhuriyet. (2013). Kılıçdaroğlu'dan Hollanda Başbakanı Rutte'ye mektup [Letter from Kılıçdaroğlu to Dutch Prime Minister Rutte]. Retrieved from http://www.cumhuriyet.com.tr/haber/diger/ 429158/Kilicdaroglu_dan_Hollanda_Basbakani_Rutte_ye_mektup.html.

Cumhuriyet. (2016). Kılıçdaroğlu'ndan AB'ye Erdoğan çağrısı [Kılıçdaroğlu's Erdoğan call to the EU]. Retrieved from http://www.cumhuriyet.com.tr/haber/siyaset/636341/ Kilicdaroglu_ ndan_AB_ye_Erdogan_cagrisi.html.

Cumhuriyet. (2018). Bahçeli'den AB'nin Türkiye'yi kınayan kararına tepki: Türkiye korsan bir devlet değildir [Bahçeli's reaction to the EU's comdemnation of Turkey: Turkey is not a rogue state]. Retrieved from http://www.cumhuriyet.com.tr/haber/siyaset/949137/ Bahceli_den_AB_nin_ Turkiye_yi_kinayan_kararina_tepki_Turkiye_korsan_bir_devlet_degildir.html.

Çınar, M. (2008). The Justice and Development Party and the Kemalist establishment. In Ü. Cizre (Ed.), Secular and Islamic politics in Turkey: The making of the Justice and Development Party (pp. 109-131). London and New York: Routledge.

Dikici Bilgin, H. (2017). Westernist sceptics and anti-western reformers in the Turkish party system. Journal of Balkan and Near Eastern Studies, 19(2), 191-208. https://doi.org/10.1080/19448953.2016.1155904

Erdoğan, R. T. (2011). Erdoğan'dan Ahmet Altan'a yanıt [Erdoğan's response to Ahmet Altan]. Vatan Gazetesi, Retrieved from http://haber.gazetevatan.com/Erdogandanahmet-altana-yanit/ 382348/9/Siyaset.

European Parliament. (2013, 11 June). Resolution on the situation in Turkey (No. B7-0309/2013). Retrieved from https://www.europarl.europa.eu/sides/getDoc.do?reference=B7-20130309\&type $=$ MOTION\&language $=$ EN\&redirect

Eylemer, S. and Taş, İ. (2007). Pro-EU and eurosceptic circles in Turkey. Journal of Communist Studies and Transition Politics, 23(4), 561-577. https://doi.org/10.1080/13523270701674657

Göçek, M. (2011). The Transformation of Turkey: Redefining state and society from the Ottoman Empire to the modern era. London: I. B. Tauris.

Guida, M. (2008). The Sèvres syndrome and "komplo" theories in the islamist and secular press. Turkish Studies, 9(1), 37-52. https://doi.org/10.1080/14683840701813994

Gülmez, S. B. (2008). The EU policy of the Republican People's Party: An inquiry on the opposition party and euro-skepticism in Turkey. Turkish Studies, 9(3), 423-436. https://doi.org/10.1080/14683840802267389

Gülmez, S. B. (2013a). The EU policy of the Republican People's Party (CHP) under Kemal Kılıçdaroğlu: A new wine in an old wine cellar. Turkish Studies, 14(2), 311-328. https://doi.org/10.1080/14683849.2013.802924

Gülmez, S. B. (2013b). Rising euroscepticism in Turkish politics: The cases of the AKP and the CHP. Acta Politica, 48(3), 326-344. https://doi.org/10.1057/ap.2013.2 
Gülmez, S. B. (2014). Understanding the euroscepticism in Turkish politics (Unpublished doctoral dissertation). Royal Holloway University of London, Egham, United Kingdom.

Gülmez, S. B. (2018). Cosmopolitan diplomacy. In G. Delanty (Ed.), Routledge international handbook of cosmopolitanism studies (2nd ed.), (pp. 430-439). London: Routledge.

Gümrükçü, T. (2018). Turkey's Erdogan tells ministers to stop using U.S. firm McKinsey. Reuters. Retrieved from https://www.reuters.com/article/us-turkey-economy-erdogan/turkeys-erdogantells-ministers-to-stop-using-u-s-firm-mckinsey-idUSKCN1MG074?feedType= RSS\&feedName=topNews\&utm_medium=Social\&utm_source=twitter.

Günay, C. and Dzihic, V. (2016). Decoding the authoritarian code: Exercising "legitimate" power politics through the ruling parties in Turkey, Macedonia and Serbia. Southeast European and Black Sea Studies, 16(4), 529-549. https://doi.org/10.1080/14683857.2016.1242872

Güneş-Ayata, A. (2003). From euro-scepticism to Turkey-scepticism: Changing political attitudes on the European Union in Turkey. Journal of Southern Europe and the Balkans, 5(2), 205-222. https://doi.org/10.1080/1461319032000097941

Habertürk. (2007). Genel seçim 2007 [General Elections 2007]. Retrieved from https://www.haberturk.com/secim2007.

Heper, M. and İnce, B. (2006). Devlet Bahçeli and "far right" politics in Turkey, 1999-2002. Middle Eastern Studies, 42(6), 873-888. https://doi.org/10.1080/00263200600922981

Hooghe, L. and Marks, G. (2009), A postfunctionalist theory of European integration: From permissive consensus to constraining dissensus. British Journal of Political Science, 39(1), 123. https://doi.org/10.1017/S0007123408000409

Hürriyet. (2013). Kılıçdaroğlu'ndan Almanya Başbakanı Merkel'e mektup [Letter from Kılıçdaroğlu to German Chancellor Merkel]. Retrieved from http://www.hurriyet.com.tr/ gundem/kilicdaroglundan-almanya-basbakani-merkele-mektup-23551250.

Hürriyet. (2017). Bahçeli'den hükümete ilk eleştiri' [Bahçeli's first criticism of the government]. Retrieved from http://www.hurriyet.com.tr/gundem/bahceli-15-temmuz-sonrasinda-avrupaayakta-alkislamaliydi-40396424.

Hürriyet. (2018). 24 Haziran 2018 Cumhurbaşkanlığı seçim sonuçları [24 June 2018 Presidential Elections Results]. Retrieved from http://www.hurriyet.com.tr/secim/24-haziran-2018secimleri/.

Hürriyet Daily News. (2013). Turkey may face 'tough' EU report. Retrieved from http://www.hurriyetdailynews.com/turkey-may-face-tough-eu-report.aspx?PageID=238\&NID= 55649\&NewsCatID=338.

Hürriyet Daily News. (2018). Turkey and Netherlands agree to 'normalize diplomatic ties' after sour period. Retrieved from http://www.hurriyetdailynews.com/turkey-and-netherlands-agree-tonormalize-diplomatic-ties-after-sour-period-134799.

İçener, E. (2016). Turkey - EU relations after the failed July 15 coup attempt. Bilig, 79, 69-87. Retrieved from www.jstor.com

İçener, E. and Çağliyan-İçener, Z. (2011). The Justice and Development Party's identity and its role in the EU's decision to open accession negotiations with Turkey. Southeast European and Black Sea Studies, 11(1), 19-34. https://doi.org/10.1080/14683857.2011.556426

Kaya, A. (2017). Europeanization of civil society in Turkey: Legacy of the \#Occupygezi movement. Turkish Studies, 18(1), 125-156. https://doi.org/10.1080/14683849.2016.1258552

Kaya, A. (2020). Right-wing populism and islamophobism in Europe and their impact on Turkey-EU relations. Turkish Studies, 21(1), 1-28. doi: 10.1080/14683849.2018.1499431

Keyman, E. F. and Aydın-Düzgit, S. (2013). Transforming Turkey-EU relations: Ground for hope?. In S. Aydın-Düzgit, A. Duncker, D. Huber, E. F. Keyman, and N. Tocci (Eds.), Global Turkey in Europe: Political, economic and foreign policy dimensions of Turkey's evolving relationship with the EU (pp. 275-282). Retrieved from ww.jstor.org 
Kirişci, K. (2006). Turkey's foreign policy in turbulent times (European Union Institute for Security Studies Chaillot Papers No 92). Retrieved from https://www.iss.europa.eu/content/turkeysforeign-policy-turbulent-times

Langan, M. (2017). Virtuous power Turkey in Sub-Saharan Africa: The 'Neo-Ottoman' challenge to the European Union. Third World Quarterly, 38(6), 1399-1414. https://doi.org/10.1080/01436597.2016.1229569

Marks, G., Hooghe, L., Nelson, M. and Edwards, E. (2006). Party competition and European Integration in the East and West different structure, same causality. Comparative Political Studies, 39(29), 155-175. https://doi.org/10.1177\%2F0010414005281932

Nefes, T. S. (2013). Political parties' perceptions and uses of anti-Semitic conspiracy theories in Turkey. The Sociological Review, 61(2), 247-264. https://doi.org/10.1111/1467-954X.12016

NTV. (2018). Bahçeli: Avrupa Birliği kapısı ardına kadar kapandı [Bahçeli: the European Union's door has shut down completely]. Retrieved from https://www.ntv.com.tr/turkiye/bahceliavrupa-birligi-kapisi-ardina-kadar-kapandi,WQGYYRcGYE6nX5XMNhlWZg.

Onursal-Beşgül, Ö. (2016). Policy transfer and discursive de-Europeanisation: Higher education from Bologna to Turkey. South European Society and Politics, 21(1), 91-103. https://doi.org/10.1080/13608746.2016.1152019

Öniş, Z. (2003). Globalization, democratization and the far right: Turkey's Nationalist Action Party in critical perspective. Democratization, 10(1), 27-52. https://doi.org/10.1080/ 13510340312331 294017

Öniş, Z. (2007). Conservative globalists versus defensive nationalists: Political parties and paradoxes of Europeanization in Turkey. Journal of Southern Europe and the Balkans, 9(3), 247-261. https://doi.org/10.1080/14613190701689902

Öniş, Z. (2010). Contesting for Turkey's political 'centre': Domestic politics, identity conflicts and the controversy over EU membership. Journal of Contemporary European Studies, 18(3), 361376. https://doi.org/10.1080/14782804.2010.507919

Saatçioğlu, B. (2010). Unpacking the compliance puzzle: The case of Turkey's AKP under EU conditionality (Kolleg-Forschergruppe Working paper No.14). Retrieved from https://ideas.repec.org/p/erp/kfgxxx/p0014.html

Saatçioğlu, B. (2016). De-Europeanisation in Turkey: The case of the rule of law. South European Society and Politics, 2l(1), 133-146. https://doi.org/10.1080/13608746.2016.1147994

Saatçioğlu, B. and El Basani, A. (2013). The AKP's shifting support for EU accession: Secular constraints, organizational capacities and religious ideas. In C. Firat and L. Hoffmann (Eds.), Turkey and the European Union: Facing new challenges and opportunities (pp. 138-155). Abingdon: Routledge.

Sabah. (2017). MHP lideri Bahçeli: 16 Nisan'dan sonra Avrupa sallanacak [MHP leader Bahçeli: Europe will tremble after 16 April]. Retrieved from https://www.sabah.com.tr/gundem /2017/03/18/MHP-lideri-bahceli-ilk-anayasa-mitinginde-konusuyor-canli.

Semo, M., Jégo, M. and Ayad, C. (2016, 8 August). Recep Tayyip Erdogan: Les occidentaux ont laissé les Turcs seuls. Le Monde. Retrieved from https://www.lemonde.fr/europe/article/2016/08/08/recep-tayyip-erdogan-les-occidentaux-ontlaisse-les-turcs-seuls_4979765_3214.html.

Sitter, N. (2001). The politics of opposition and European integration in Scandinavia: Is Euroscepticism a government-opposition dynamic?. West European Politics, 24(4), 22-39. https://doi.org/10.1080/01402380108425463

Soyaltın-Colella, D. and Akdeniz-Göker, E. (2019). De-Europeanisation and equal citizenship in Turkey: The case of circassians. The International Spectator, 54(4), 62-77. https://doi.org/10.1080/03932729.2019.1666233 
Sözcü. (2015). Türkiye'nin, AB'nin toplama kampı olmasına vize vermem [I won’t endorse Turkey to become the EU's concentration camp]. Retrieved from https://www.sozcu.com.tr/2015/ gundem/turkiyenin-abnin-toplama-kampi-olmasina-vize-vermem-969191/.

Spiering, M. (2007). Euro-sceptic concerns about national identity in the European Union and Turkey. In E. Lagro and K. E. Jorgensen (Eds.), Turkey and the Euroean Union: Prospects for a ifficult encounter (pp. 169-184). Basingstoke: Palgrave Macmillan.

Taggart, P. (1998). A touchstone of dissent: Euroscepticism in contemporary western European party systems. European Journal of Political Research, 33(3), 363-388. https://doi.org/10.1111/1475-6765.00387

Taggart, P. and Szczerbiak, A. (2004). Contemporary Euroscepticism in the party systems of the European Union candidate states of Central and Eastern Europe. European Journal of Political Research, 43(1), 1-27. https://doi.org/10.1111/j.1475-6765.2004.00143.x

Takvim. (2017). Avrupa'nın şer ittifakı [The unholly alliance of Europe]. Retrieved from https://www.takvim.com.tr/guncel/2017/04/11/avrupanin-ser-ittifaki.

Tasch, B. (2016, 8 August). The West 'contradicts the values it is defending': Erdogan blasts the international response to the Turkey coup. Business Insider UK. Retrieved from http://uk.businessinsider.com/erdogan-blasts-international-response-to-turkey-coup-refugeecrisis-2016-8.

TBMM. (2008a). TBMM tutanak dergisi [Turkish Parliament's Parliamentary Minutes Journal], [Term 23, Legislative Year 2, Volume 15, Session 67, 20 February].

TBMM. (2008b). TBMM tutanak dergisi [Turkish Parliament's Parliamentary Minutes Journal], [Term 23, Legislative Year 2, Volume 22, Session 117, 12 June].

Tezcan, E. and Aras, İ. (2015). Adalet ve Kalkınma Partisi'nde Euroseptisizm: Avrupa Birliği desteğinin eleştiriye dönüşümü. Uluslararası Hukuk ve Politika, 11(41), 1-35. Retrieved from www.jstor.com

Timur, Ş. and Nordland, R. (2016, 25 November). Erdogan threatens to let migrant flood into Europe resume. The New York Times. Retrieved from https://www.nytimes.com/2016/11/25/ world/europe/turkey-recep-tayyip-erdogan-migrants-european-union.html.

Toksabay, E. and Karadeniz, T. (2017, 6 July). EU parliament calls for Turkey accession talks to be suspended. Reuters. Retrieved from https://www.reuters.com/article/us-turkey-euparliament/eu-parliament-calls-for-turkey-accession-talks-to-be-suspended-idUSKBN19R194.

Vachudova, M. A. (2014). EU leverage and national interests in the Balkans: The puzzles of enlargement ten years on. Journal of Common Market Studies, 52(1), 122-138. https://doi.org/10.1111/jcms.12081

Yaka, Ö. (2016). Why not EU? Dynamics of the changing Turkish attitudes towards EU membership. Journal of Contemporary European Studies, 24(1), 149-170. https://doi.org/10.1080/14782804.2015.1056726

Yavuz, H. M. (2009). Secularism and Muslim democracy in Turkey. Cambridge: Cambridge University Press.

Y1lmaz, H. (2006). Two pillars of nationalist Euroskepticism in Turkey: The Tanzimat and Sevres syndromes. In I. Karlsson and A. Strom Melin (Ed.), Turkey, Sweden and the European Union: Experiences and expectations (pp. 29-40). Stockholm: Swedish Institute for European Policy Studies.

Yilmaz, H. (2009). The International context. In C. W. Haerpfer, P. Bernhagen, R. F. Inglehart and C. Welzel (Eds.), Democratization (pp. 92-106). Oxford: Oxford University Press.

Yilmaz, H. (2011). Euroscepticism in Turkey: Parties, elites, and public opinion. South European Society and Politics, 16(1), 185-208. https://doi.org/10.1080/13608741003594353 
S. B. Gülmez, "Rethinking Euroscepticism in Turkey: Government, Opposition and Public Opinion"

Yılmaz, G. (2016a). From Europeanization to de-Europeanization: The Europeanization process of Turkey in 1999-2014. Journal of Contemporary European Studies, 24(1), 86-100. https://doi.org/10.1080/14782804.2015.1038226

Yılmaz, G. (2016b). Europeanisation or de-Europeanisation? Media freedom in Turkey (1999-2015). South European Society and Politics, 21(1), 147-161. https://doi.org/10.1080/13608746.2016.1148102

Wódka, J. (2016). Transnational cooperation of Turkish political parties as an ineffective tool of Europeanization. Southeast European and Black Sea Studies, 16(2), 295-315. https://doi.org/10.1080/14683857.2016.1168640 